\title{
POLITICAL WILL PEMILIH FIGUR KEPEMIMPINAN CALON KEPALA DESA
}

\author{
Rohmat \\ IAIN Surakarta \\ Email: r_ohmat@yahoo.com
}

\section{Abstract}

The study aims to know political will of the voters the leadership figure of the village chief candidate in rural community development in the Sanggung village, Gatak District, Sukabarjo, 2012. This study used a descriptive approach. The population in this study is 1500 suffrage and sample is 100 suffrage. The instruments to collect data using questionnaires. The data analysis using the percenlage (percentile). The results of this study found that political will of the voters the leadership figure of the village chief candidate in doing the task of rural community development, that is: the initialives (98\%); the priority ( $82 \%)$; oriented mobilization of community development $(50 \%)$; emplosizing the rule of law in the form of severe punishment for comption (40\%); business sustainability minded (99\%); attention by giving passion and spirit new life and eliminate the monotony of village life (97\%); influential in improving the socio-economic welfare (100\%); improving education (84\%); undertake modernization in the field of transport and technology (100\%); did not contest the figure gender prospective village chief $(69 \%)$ and the changes $(94 \%)$.

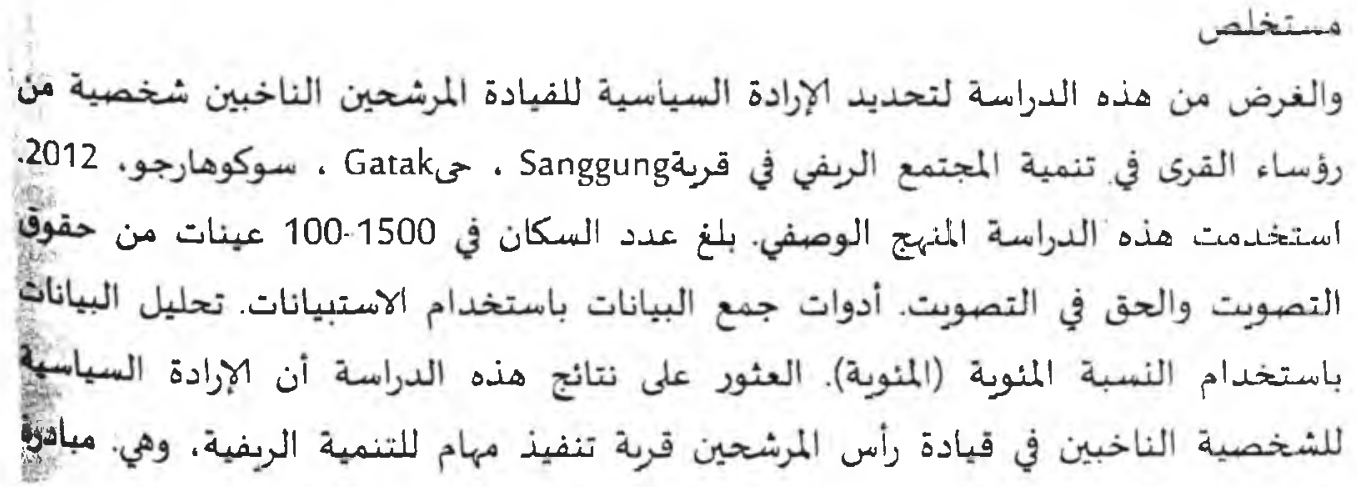




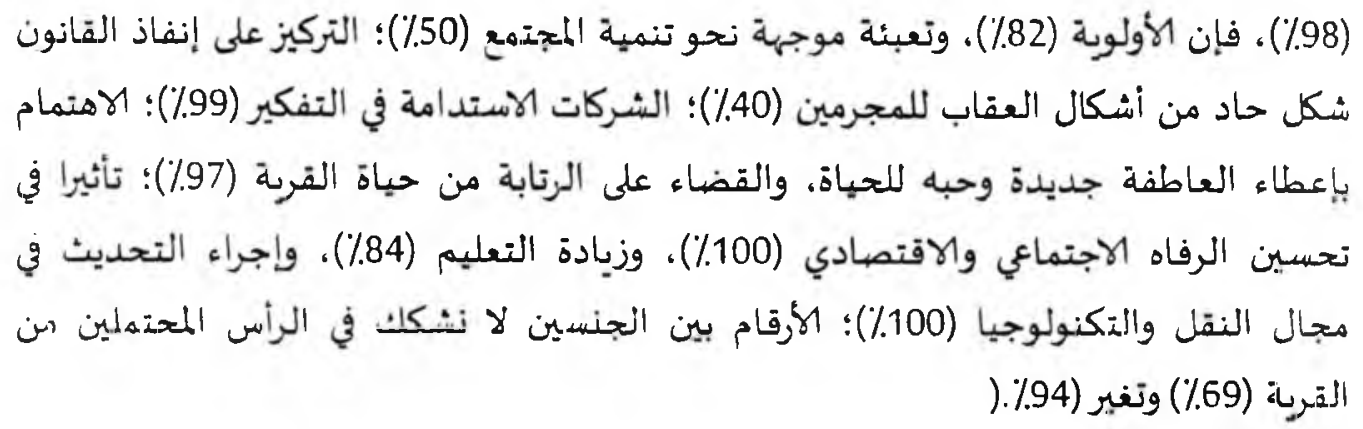

Kaywords: Political will, leadership of village chief, community development.

\section{A. Pendahuluan}

Dalam pembangunan bangsa, mempertimbangkan diantaranya: landasan ideal bangsa; pijakan konstitusi negara; kebinekatunggalikaan; dasar operasional dan political will. Political wili ini akan memberi corak dalam pembangunan masyarakat, termasuk pembangunan masyarakat pedesaan. Moeljarto Tjokrowinoto (1977) menyatakan bahwa, pembangunan masyarakat desa merupakan suatu bentuk tindakan kolektif suatu masyarakat desa yang bertujuan untuk meningkatka taraf hidup masyarakat tersebut dalam arti material dan spiritual. '

Selanjutnya, Khairuddin (1992) mengemukakan bahwa pembangunan masyarakat desa sebagai bagian dari pembangunan nasional, tentu saja mempunyai tujuan-tujuan yang tidak terlepas dari pembangunan secara keseluruhan. Karena kondisi pedesaan mempunyai spesifikasi tertentu, baik dalam bidang sosial maupun ekonomi, maka tujuan pembangunan masyarakat di pedesaan lebih sering ditekankan pada bidang ekonomi, sebab kondisi ekonomi inilah yang pada umumnya sangat memperihatinkan. Oleh karena itu pembangunan pedesaan diarahkan pada peningkatan taraf hidup masyarakat. ${ }^{2}$

Demikian halnya pembangunan pedesaan di Desa Sanggung, Kecamatan Gatak, Kabupaten Sukoharjo, Propinsi Jawa Tengah diharapkan dapat

\footnotetext{
${ }^{1}$ Moeljarto Tjokrowinoto, Peranan Kebudayaan Politik dan Kebudayaan Administrasi di dalam Pembangunan Masyarakat Desa, dalam Buletin Balai Pembinaan Administrasi, Universitas Gadjah Mada, No.3/1977.

${ }^{2}$ Khairuddin, Pembangunan Masyarakat, (Yogyakarta, Liberty, 1992)
} 
menggerakkan potensi sumber daya manusia dan sumber daya alam. Untuk itu, masyarakat desa tersebut memperhitungkan kepada figure kepemimpinan calon kepala desa yang akan memimpin sebagai kepala desa. Sehubungan dengan hal tersebut, maka masyarakat sebagai pemilih frgur calon kepala desa mengedepankan pemimpin yang terus menerus memiliki good will be. Kenyataannya, kepala desa dimaksud sebelumnya terlibat persoalan hukum, bahkan pernah menjadi urusan pengadilan. Selain itu, kepala desa sebelumnya juga terkesan memiliki problem mengarah kepada persoalan hukum sampai meninggal dunia sebelum masa jabatan habis.

Figur kepala desa, desa dimaksud selama ini bukan gender. Hal ini, dimungkinkan probabilitasnya yang memenuhi persyaratan termasuk diterima oleh pemilih figur bukan gender sekalipun belum menjadi jaminan sebagai kepala desa dapat memimpin masyarakat pedesaan yang maju, sejahtera dan damai. Dekade ini, pembangunan pedesaan yang juga sering disebut community development memberikan peluang besar keterlibatan masyarakat dalam pembangunan pedesaan. Begitu pula masyarakat pedesaan desa Sanggung, nampak mengalami pergeseran yang peduli untuk pembangunan desanya, sehingga kepala desa yang diharapkan dapat mewujudkan masyarakat adil dan makmur berdasarkan Pancasila yang diridhoi oleh Tuhan Yang Maha Esa.

Untuk itu, masyarakat yang akan memilih frgur calon kepala desa menegaskan untuk bisa membawa kepada perubahan yang memberi gairah dan sernangat hidup baru serta menghilangkan monoton dari kehidupan desa, sehingga warga desa tidak merasa jenuh dengan lingkungan hidupnya. Dengan demikian, masyarakat akan meningkat kesejahtaraan sosial ekonomi maupun pendidikannya. Oleh karena itu, masyarakat pemilih figur calon kepala desa membuka peluang kepada calon yang mempunyai kemampuan seperti yang dilharapkan oleh masyarakat pemilihnya. Sehubungan dengan uraian hal tersebut ii atas, maka diperlukan informasi dengan melakukan penelitian. Maka dari itu, benulis mengkaji melalui penelitian dengan judul "Political will Pemilih, Figur Kepemimpinan Calon Kepala Desa dalam Pembangunan Masyarakat Pedesaan Desa Sanggung, Kecamatan Gatak, Kabupaten Sukoharjo, Propinsi Jawa (xingah Tahun 2012". 


\section{B. Kajian Teori \\ B.1. Political will}

1. Pengertian Political will

Craig Charney (2009) menyatakan bahwa, to advocates, politicians, and organizations promoting change, "political will" is the holy grail. When advocates argue, politicians vote, and organizations campaign, they say they are trying to shape or respond to political wrill. Political will is the ghost in the machine of politics, the motive force that generates political action. ${ }^{3}$ Selanjutnya, Nadyafirdhani (2012) mengemukakan bahwa political mill merupakan sebuah kemauan suatu negara yang dalam perwujudannya dibutuhkan dukungan dari rakyatnya. ${ }^{4}$

\section{Indikator political will}

Derick (1999) mengemukakan beberapa indikator yang bisa dipergunakin untuk mengukur political will pemerintah, yaitu: $:^{5}$

a. Inisiatif. Dari mana sebetulnya inisiatif pemberantasan korupsi? Apakah pemerintah memiliki inisiatif untuk memberantas korupsi?

b. Prioritas. Apakah pemerintah telah melakukan kajian mendalam dan menentukan sektor mana yang akan menjadi prioritas utama yang menjadi target pemberantasan korupsi? Pemilihan prioritas sangat penting karena korupsi di Indonesia sudah sangat sistemik dan meluas di berbagai sektor.

c. Mobilisasi dukungan politik. Ada tidaknya kemauan politik juga tergantung pada kemauan dan kemampuan untuk menggalang dukungan bagi program anti korupsi. Program anti korupsi yang dijalankan pemerintah harus mendapat dukungan dari kekuatan politik

\footnotetext{
${ }^{3}$ Craig Charney, Political Will: What is it? How is it Measured?, (New York: Charney Research, 2009)

" Nadyafirdhani, "National Power" dikutip dari http://nadyafirdhanifisip12.wcb.unair.ac.id/arikel detail-61768-Umum-Narional\%20Power.heml

${ }^{5}$ Derick W'. Brinkerhoff, State-Civil Society Networks For Policy Implementation In Developing Countries dalam Review of Policy Research, Volume 16, Issue 1, pages 123-147, March 1999.
} 
lain. Kalau tidak ada dukungan, riwayat pemerintah akan singkat karena keburu digantikan pemerintah baru. Tanpa dukungan politik juga bisa menjadikan pemberantasan korupsi macet karena pemerintah mesti berkompromi dengan kekuatan politik lain.

d. Penegakan hukum berupa hukuman yang berat bagi koruptor. Tanpa sanksi yang berat, orang tidak akan jera melakukan korupsi. Korupsi pada dasarnya memiliki benefit atau keuntungan tinggi. Nah, kalau cost atau konsekuensinya tinggi, seperti sanksi hukuman, orang akan takut. Tetapi kalau tidak ada atau cost rendah, orang akan berani melakukan korupsi.

e. Kebetlanjutan usaha. Apakah program pemberantasan korupsi merupakan usaha yang diikhtiarkan terus menerus? Ataukah hanya untuk kepentingan sesaat, misalnya menjelang Pemilu.

\section{B.2. Kepemimpinan}

1. Pengertian Kepemimpinan

Stoner, Freeman, dan Gilbert (1995) menyatakan bahwa kepemimpinan adalah the process of directing and influencing the task related activities of group members. Kepemimpinan adalah proses dalam mengarahkan dan mempengaruhi para anggota dalam hal berbagai aktivitas yang harus dilakukan." Selain itu, Jacob\&Jacques (1990) mengungkapkan bahwa kepemimpinan adalah sebuah proses memberi arti (pengarahan yang berarti) terhadap usaha kolektif dan yang mengakibatkan kesediaan untuk melakukan usaha yang diinginkan untuk mencapai sasaran. ${ }^{7}$

Selanjutnya, Mochammad Teguh (2001) menyatakan bahwa kepemimpinan berarti mempengaruhi orang lain untuk mengambil tindakan, artinya seorang pemimpin harus berusaha mempengaruhi pengikutnya dengan berbagai cara seperti menggunakan otoritas yang

\footnotetext{
${ }^{6}$ Stoner, Freeman, dan Gilbert, Management, (US, Prentice Hall, 1995)

7 Jacobs, T. O., and E. Jaques, Measures of Leadership, (NJ: Leadership Library of America, Inc, 1990)
} 
terlegitimasi, menciptakan model (menjadi teladan), penetapan sasaran, memberi imbalan dan hukuman, restrukturisasi organisasi dan mengkomunikasikan sebuah visi. Dengan demikian, seorang pemimpin dapat dipandany efektif apabila dapat membujuk para pengikutnya untuk meninggalkan kepentingan pribadi mereka demi keberhasilan organisasi. ${ }^{8}$

2. Fungsi Kepemimpinan

Dedi (2012) mengemukakan beberapa fungsi dalam kepemimpinan, yaitu:?

a. Pemimpin sebagai eksekutif (Executive Leader)

Sering kali disebut sebagai administrator atau manajer. Fungsinya adalah menerjemahkan kebijaksanaan menjadi suatu kegiatan, dia memempin dan mengawasi tindakan orang-orang yang menjadi bawahannya. Dan membuat keputusan-keputusan yang kemudian memerintahkannya untuk dilaksanakan. Kepemimpinan ini banyak ditemukan didalam masyarakat dan biasanya bersifat kepemerintahan, mulai dari pusat sampai ke daerah-daerah memerlukkan fungsi tersebut.

b. Pemimpin scbagai penengah

Dalam masyarakat modern, tanggung jawab keadilan terletak di tangan pemimpin dengan keahliaanya yang khas dan ditunjuk secara khusus. Ini dikenal dengan pengadilan. Dan bidang lainnya, umpamanya dalam bidang olahraga, terdapat wasit yang mempunyai tugas sebagai wasit.

c. Pemimpin sebagai penganjur

Sebagai propagandis, sebagai juru bicara, atau sebagai pengarah opini merupakkan orang-orang penting dalam masyarakat. Mereka bergerak dalam bidang komunikasi dan publistik yang menguasai ilmu komunikasi. Penganjur adalah sejenis pemimpin yang memberi inspirasi kepada orang lain. Seringkali ia merupakkan orang yang pandai bergaul dan fasih berbicara.

8 Mochammad Teguh, Lathan Kepemimpinan Islam Tingkat Dasar (I.KIDI), (Yogyakarta, UII Press, 2001)

9 Dedi "Kepemimpinan" dikutip dari hrtp: / hlog.binadarma.ac.id/dedi1968/wpontent/uploads/2012/09/kepemimpinan.pdf 
d. Pemimpin sebagai ahli

Pemimpin sebagai ahli dapat dianalogikan sebagai instruktur atau seorang juru penerang, berada dalam posisi yang khusus dalam hubungannya dengan unit sosial dimana dia bekerja. Kepemimpinannya hanya berdasarkan fakta dan hanya pada bidang dimana terdapat fakta. Termasuk dalam kategori ini adalah guru, petugas susial, dosen, dokter, ahli hukum, dan sebagainya yang mencapai dan memelihara pengaruhnya karena mereka mempunyai pengetahuan untuk diberikkan kepada orang lain

e. Pemimpin diskusi

Tipe pemimpin yang seperti ini dapat dijumpai dalam lingkungan kepemimpinan yang demokratis dimana komunikasi memegang peranan yang sangat penting. Seseorang yang secara lengkap memenuhi kriteria kepemimpinan demokratis ialah orang yang menerima peranannya sebagai pemimpin diskusi.

\section{Tipe Kepemimpinan}

Tipe kepemimpinan yang dimiliki seorang pemimpin akan mempengaruhi organisasi yang dipimpinnya. Dedi (2012) menyebutkan tipe-tipe kepemimpinan adalah: ${ }^{10}$

a. Tipe Otokratik

Dilihat dari persepsinya seorang pemimpin yang otokratik adalah seorng yang sangat egois. Seorang pemimpin yang oturiter akan menunjuukkan sikap yang menonjol "keakuannya".

b. Tipe Paternalistik

Tipe pemimpin patemalistik hanya terdapat dilingkungan masyarakat yang bersifat tradisional, umumnya dimasyarakat agraris. Salah satu ciri utama masyarakat tradisional ialah rasa hormat yang tinggi yang ditujukan oleh para anggota masyarakat kepada orang tua atau seseorang yang dituakan. Pemimpin seperti ini kebapakan, sebagai tauladan atau panutan masyarakat. Biasanya tokoh-tokoh adat, para 
ulama dan guru. Pemimpin ini sangat mengembangkan sikap kebersamaan.

c. Tipe Kharismatik

Tidak banyak hal yang dapat disimak dari literatur yang ada tentang kriteria kepemimpinan yang kharismatik. Memang ada karakteristiknya yang khas yaitu daya tariknya yang sangat memikat sehingga mampu memperoleh pengikut yang jumlahnya kadang-kadang sangat besar. Tegasnya seorang pemimpin yang kharisnatik adalah seseorang yang dikagumi oleh banyak pengikut meskipun para pengikut tersebut tidk selalu dapat menjelaskan secara konkret mengapa orang tersebut dikagumi.

d. Tipe Laissez Faire

Pemimpin ini berpandangan bahwa umumnya organisasi akan berjalan lancar dengan sendirinya karena para anggota organisasi terdiri ari orang-orang yang sudah dewasa yang mengetahui apa yang menjadi tujuan organisasi, sasaran-sasaran apa yang ingin dicapai, tugas yang harus ditunaikan oleh masing-masing anggota dan pemimpin tidak terlalu sering intervensi.

e. Tipe Demokratis

Pemimpin yang demokratik biasanya memandang peranannya selaku koordinator dan integrator dari berbagai unsur dan komponen organisasi. Menyadari bahwa mau tidak mau organisasi harus disusun sedemikian rupa sehingga menggambarkan secara jelas aneka ragam tugas dan kegiatan yang tidak bisa tidak harus dilakukan demi tercapainya tujuan. Melihat kecenderungan adanya pembagian peranan sesuai dengan tingkatnya. Memperlakukan manusia dengan cara yang manusiawi dan menjunjung harkat dan martabat manusia.

4. Karakter Kepemimpinan

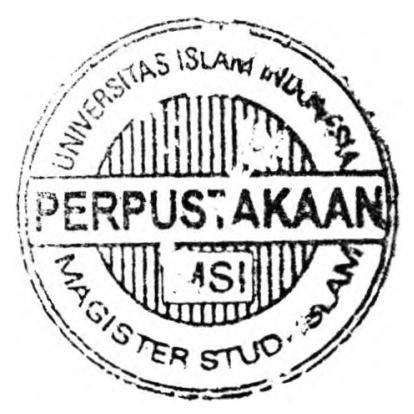


Muhammad Ryaas Rasyid (2000) mengemukakan bahwa terdapat karakter kepemimpinan politik dan pemerintahan dunia, yaitu: ${ }^{11}$

a. Kepemimpinan yang sensitif, ditandai oleh kemampuan untuk secara dini memahami dinamika perkembangan masyarakat, mengerti apa yang mereka butuhkan, mengusahakan agar menjadi pihak pertama yang memberi perhatian terhadap kebutuhan itu. Pemimpin yang sensitif adalah mengkomunikasikan kepada masyarakat tentang adanya kepedulian pemerintah atas kebutuhan.

b. Kepemimpinan yang responsif, lahir berhadapan dengan masyarakat yang cenderung lebih aktif, peminpin lebih banyak berperan menjawab aspirasi dan tuntutan masyarakat yang disalurkan melalui berbagai media komunikasi. Kepemimpinan pemerintahan yang responsif banyak ditemui pada pemerintahan yang demokratis.

c. Kepemimpinan yang defensif, ditandai dengan sifat egoistik, merasa paling benar. Kepemimpinan defensif melekat pada keberadaan seseorang yang pintar atau merasa paling pintar.

d. Kepemimpinan yang represif, cenderung sama egois dan arogannya dengan karakter yang defensif, memonopoli kebenaran, kekuasaan identik dengan kebenaran, mudah curiga dan cemburu terhadap setiap orang atau kelompok.

\section{B.3. Pembangunan masyarakat pedesaaan}

1. Pengertian pembangunan masyarakat pedesaaan

Joni Ramat mngemukakan bahwa pembangunan masyarakat desa adalah seluruh kegiatan pembangunan yang berlangsung di desa, yang meliputi seluruh aspek kehidupan masyarakat (ideologi, politik, ekonomi, sosial, budaya, dan pertahanan keamanan), dan dilaksanakan secara terpadu dengan mengembangkan swadaya gotong royong masyarakat. Pembangunan masyarakat desa mempunyai sifat integralistik yang berarti kegiatan pembangunan masyarakat desa meliputi seluruh kehidupan

1t Muhammad Ryaas Rasyid, Makna Pemetintahan, Oakarta, PT.Mutiara Sumber Widya, 
masyarakat desa. Pembangunan masyarakat desa merupakan wadah resmi dari seluruh aktivitas pembangunan yang menyangkut desa dan masyarakat desa ${ }^{12}$

Ali Hanapiah (2012) mengemukakan tentang pembangunan desa pada hakikatnya adalah segala bentuk aktivitas manusia (masyarakat dan pemerintah) di desa dalam membangun diri, keluarga, masyarakat dan lingkungan di wilayah desa baik yang bersifat fisik, ekonomi, sosial, budaya, politik, ketertiban, pertaharian dan keamanan, agama dan pemerintahan yang dilakukan secara terencana dan membawa dampak positif terhadap kemajuan desa. Dengan demikian, pembangunan desa sesungguhnya merupakan upaya-upaya sadar dari masyarakat dan pemerintah baik dengan menggunakan sumberdaya yang bersumber dari desa, bantuan pemerintah maupun bantuan organisasi-organisasi/lembaga domestik maupun internasional untuk menciptakan perubahan-perubahan ke arah yang lebih baik. $^{13}$

2.. Tujuan pembangunan masyarakat pedesaaan

Setiap pembangunan pedesaan, mempunyai tujuan. Tujuan perlu dirumuskan terlebih dahulu karena sebagai arah, pedoman, acuan, monitoring dan evaluasi terhadap semua aktivitas pembangunan pedesaan. Bintarto (1983) menyatakan bahwa tujuan pembangunan masyarakat desa adalah: ${ }^{14}$

a. Memberi gairah dan semangat hidup baru serta menghilangkan monoton dari kehidupan desa sehingga warga desa tidak merasa jemu dengan lingkungan hidupnya

b. Meningkatkan kesejahteraan sosial ekonomi warga desa sehingga dapat menahan arus urbanisasi

\footnotetext{
12 Joni Rahmat Prarriudia, Pembangunan Masyarakat, http://file.upi.edu/Dircktori/FIR/JUR, PEND. LUAR SEKOL.AH/197106141998031. LONI RAHMAT PRAMUDIA/Pembangunan Masyarakat-HO pdf

13 Ali Hanapiah, Ficnomena Pembangunan Desa, Jatinangor, Institut Pemerintahan Dalam Negeri, 2011).

${ }_{14}$ Bintarto, Interaksi Desa-Kota, Jakarta, Ghalia Indonesia, 1983)
} 
c. Meningkatkan bidang pendidikan secara merata sehingga dapat mengurangi arus pelajar ke kota dan tenaga terididik akan tetap tinggal di desa membimbing warga desa yang belum maju

d. Modernisasi di bidang pengangkutan akan secara berangsur menghilangkan sifat isolasi desa

e. Modernisasi merupakan tumpuan bagi pengembangan teknologi pedesaan dan proses pengambangannya masyarakat desa dapat diikut sertakan.

B.4. Political mill Kepemimpinan kepala desa dalam pembangunan masyarakat pedesaan

Political will merupakan kemauan politik atau harapan politik sebagai suatu tindakan dalam kegiatan yang melibatkan publik, masyarakat, baik dalam suatu organisasi masa maupun politik bertumpu kepada etika yang berlandaskan kepada Pancasila dan UUD 1945 untuk mencapai suatu tujuan.

Political will melibatkan masyarakat termasuk masyarakat pedesaan yang akan melakukan hak pilihnya untuk memilih figur kepemimpinan calon kepala desa melakukan sinergi dalam pembangunan masyarakat pedesaan. Ali hanapiah (2012) menyatakan bahwa dalam menyusun perencanaan pembangunan desa yang harus diperhatikan adalah harus bertolak dari kondisi existing desa tersebut. Esensi dari pembangunan desa adalah "bagaimana desa dapat membangun/ memanfaatkan/ mengeksploitasi dengan tepat (optimal, efektif dan efisien) segala potensi dan sumber daya yang dimiliki desa untuk memberikan rasa aman, nyaman, tertib serta dapat meningkatkan kesejahteraan masyarakat desa. 15

\section{Metode Penelitian}

1. Pendekatan Penelitian

Pendekatan penelitian ini menggunakan pendekatan penelitian deskriptif. Suharsimi Arikunto (2002) berpendapat bahwa pada umumnya

15 Ibid 13 
penelitian deskriptif merupakan penelitian non hipotesa, sehingga dalam rangka penelitiannya tidak perlu merumuskan hipotesis. ${ }^{16}$

Dalam penelitian ini peneliti mendidkripsikan data dengan kata-kata, kalimat dan mengurai bukan dengan angka. Moleong (2008) menyatakan bahwa penelitian mengedepankan data dengan berlandaskan pada pengungkapan apa-apa yang diungkapkan oleh responden dari data yang dikumpulkan berupa kata-kata, gambar, dan bukan angka-angka. ${ }^{17}$

2. Populasi dan Sampel

Populasi dalam penelitian ini adalah masyarakat yang memiliki hak pilih berjumlah 1500 orang. Sampel penelitian adalah $15 \%$ dari populasi yaitu 100 hak pilih. Suharsimi Arikunto (2002) mengemukakan di dalam pengambilan sampel apabila subyeknya kurang dari 100 diambil semua sehingga penelitian merupakan penelitian populasi. Selanjutnya jika jumlah subyeknya besar dapat diambil antara $10 \%-15 \%$ atau $20 \%-25 \%$ atau lebih. ${ }^{18}$

3. Instrumen Pengumpulan Data

Instrumen untuk mengumpulkan data dalam penelitian ini menggunakan angket. Borg (1983) menyatakan bahwa angket perlu diujicobakan untuk melihat pernyataan, pengungkapan kata-kata yang meragukana bagi responden. 19

\section{Analisis data}

Analisa data dengan menggunakan prosentase (persentil). Gay (1990) menegaskan bahwa analisis jawaban responden terhadap angket dapat dilakukan dengan menghitung persentase masing-masing pilihan yang tersedia pada setiap butir angket. ${ }^{20}$

16 Suharsimi Arikunto, Prosedur Penelitian, Suatu Pendekatan Praktek, Oakarta, PT. Rineka Cipta, 2002)

${ }^{17}$ Molenng, Lexy J, Metodologi Penelitian Kualitatif, (Bandung, Rosdakarya, 2008)

${ }^{18}$ Ibid 15

19 Borg, Walter R., Gall, Meredith D, Educational Research: An Introduction (4th ed.), (New York, Langman Inc., 1983)

${ }^{20}$ Gay, L.R., Educational Research: Competencies for Analysis and Application (3rd ed), (New York, Macmillan Publishing Company, 1990) 


\section{Temuan Hasil Penelitian}

Hasil penelitian ini menemukan sebagaimana pada Tabel 1 menggambarkan sebagian besar responden (98\%) menyatakan bahwa political will pemilih figur kepemimpinan calon kepala desa berinisiatif dalam pembangunan masyarakat pedesaan. Selainnya, adalah sebagian kecil responden $(2 \%)$ tidak mempunyai inisiatif bagi kepemimpinan calon kepala desa dalam pembangunan masyarakat pedesaan.

Tabel 1

Political will pemilih figur kepemimpinan calon kepala desa

\begin{tabular}{|llr|}
\hline \multicolumn{1}{|c|}{ Alternatif jawaban } & $\mathrm{f}$ & $\%$ \\
\hline 1. Mempunyai inisiatif & 98 & 98,0 \\
2. Tidak mempunyai inisiatif & 2 & 2,0 \\
\hline Jumlah & 100 & 100,0 \\
\hline
\end{tabular}

Table 2 di bawah ini, menunjukkan hasil temuan penelitian bahwa political mill pemilih figur calon kepala desa dalam melakukan tugas kepemimpinannya pada umumnya responden (82\%) menyatakan adanya prioritas. Sedangkan sedikit responden $(12 \%)$ menyatakan tidak ada ada prioritas

Tabel 2

Political will pemilih figur calon kepala desa dalam melakukan tugas kepemimpinannya

\begin{tabular}{|lll|}
\hline \multicolumn{1}{|c|}{ Alternatif jawaban } & f & $\%$ \\
\hline 1. adanya prioritas & 82 & 82,2 \\
2. tidak ada prioritas & 12 & 12,2 \\
\hline Jumlah & 100 & 100,0 \\
\hline
\end{tabular}

Mobilisasi dukungan politik seperti dinyatakan pada Table 3 sebanyak 30\% responden, untuk mobilisasi pembangunan masyarakat lebih banyak responden $\$(0 \%)$ dibanding keduanya, dan tidak banyak responden (20\%) political will 
pemilih figur calon kepala desa dalam melakukan tugas kepemimpinannya berorientasi kepada mobilisasi pembangunan pemerintahan desa.

\section{Tabel 3}

Political will pemilih figur calon kepala desa dalam melakukan tugas kepemimpinannya berorientasi

\begin{tabular}{|lll|}
\hline \multicolumn{1}{|c|}{ Alternatif jawaban } & $\mathrm{f}$ & $\%$ \\
\hline 1. mobilisasi dukungan politik & 30 & 30,0 \\
2. mobilisasi pembangunan masyarakat & 50 & 50,0 \\
3. mobilisasi pembangunan pemerintahan & 20 & 20,0 \\
desa & & \\
\hline Jumlah & 100 & 100,0 \\
\hline
\end{tabular}

Penegakan hukum berupa hukuman yang berat bagi koruptor berjumlah $40 \%$ dan baik tidak ada hukuman yang berat bagi koruptor dan melaporkan kepada penegak hukum berjumlah sama masing-masing $21 \%$, serta $18 \%$ political will pemilih figur calon kepala desa dalam menjalankan kepemimpinan menekankan kepada tidak mengambil sikap.

\section{Tabel 4}

Political will pemilih figur calon kepala desa dalam menjalankan kepemimpinan menekankan kepada

\begin{tabular}{|lcc|}
\hline \multicolumn{1}{|c|}{ Alternatif jawaban } & $\mathrm{f}$ & $\%$ \\
\hline 1. periegakan hukum berupa hukuman yang & 40 & 40,0 \\
berat bagi koruptor & & \\
2. tidak ada hukuman yang berat bagi 21 & 21,0 \\
koruptor & 18 & 18,0 \\
3. melaporkan kepada penegak hukum & & \\
4. tidak mengambil sikap & & \\
\hline Jumlah & 100 & 100,0 \\
\hline
\end{tabular}

Hampir semua responden (99\%) menyatakan bahwa political will pemilih figur calon kepala desa dalam menjalankan kepemimpinan berwawasan keberlanjutan usaha, dan hampir tidak ada responden (1\%) menyatakan bahwa political will 
pemilih figur calon kepala desa dalam menjalankan kepemimpinan berwawasan tidak melanjutkan usaha.

Tabel 5

Political will pemilih figur calon kepala desa dalam menjalankan kepemimpinan berwawasan

\begin{tabular}{|llc|}
\hline \multicolumn{1}{|c|}{ Alternatif jawaban } & F & $\%$ \\
\hline 1. keberlanjutan usaha & 99 & 99,0 \\
2. tidak melanjutkan usaha & 1 & 1,0 \\
\hline Jumlah & 100 & 100,0 \\
\hline
\end{tabular}

Responden (97\%) menyatakan bahwa political will pemilih figur kepemimpinan calon kepala desa dalam pembangunan pedesaaan memperhatikan dengan memberi gairah dan semangat hidup baru serta menghilangkan monoton dari kehidupan desa, hanya 3\% responden kurang memberi gairah dan semangat hidup baru serta menghilangkan monoton dari kehidupan desa, sedangkan responden lainnya masing-masing $0 \%$ atau tidak ada yang menyatakan tidak dan sama sekali tidak memberi gairah dan semangat hidup baru serta menghilangkan monoton dari kehidupan desa.

Tabel 6

Political will pemilih figur kepemimpinan calon kepala desa dalam pembangunan pedesaaan memperhatikan dengan

\begin{tabular}{|c|c|c|}
\hline Alternatif jawaban & $\mathrm{F}$ & $\%$ \\
\hline $\begin{array}{l}\text { 1. memberi gairah dan semangat hidup } \\
\text { baru serta menghilangkan monoton } \\
\text { dari kehidupan desa }\end{array}$ & 97 & 97,0 \\
\hline $\begin{array}{l}\text { 2. kurang memberi gairah dan semangat } \\
\text { hidup baru serta menghilangkan } \\
\text { monoton dari kehidupan desa }\end{array}$ & 3 & 3,0 \\
\hline $\begin{array}{l}\text { 3. tidak memberi gairah dan semangat } \\
\text { hidup baru serta menghilangkan } \\
\text { monoton dari kehidupan desa }\end{array}$ & 0 & 0,0 \\
\hline
\end{tabular}




\begin{tabular}{|l|l|l|}
\hline $\begin{array}{l}\text { 4. sama sekali tidak memberi gairah dan } \\
\text { semangat hidup baru serta } \\
\text { menghilangkan monoton dari }\end{array}$ & 0,0 \\
kehidupan desa & & \\
\hline Jumlah & 100 & 100,0 \\
\hline
\end{tabular}

Tidak ada responden $(0 \%)$ yang menyatakan bahwa political will pemilih figur kepemimpinan calon kepala desa dalam pembangunan pedesaaan tidak berpengaruh dalam peningkatan kesejahteraan sosial ekonomi, jadi semua responden $(100 \%)$ menyatakan bahwa political will pemilih figur kepemimpinan calon kepala desa dalam pembangunan pedesaaan berpengaruh dalam peningkatan kesejahteraan sosial ekonomi

\section{Tabel 7}

Political will pemilih figur kepemimpinan calon kepala desa dalam pembangunan pedesaaan

\begin{tabular}{|clc|}
\hline \multicolumn{1}{|c|}{ Alternatif jawaban } & F & $\%$ \\
\hline 1. $\begin{array}{l}\text { meningkatkan kesejahteraan sosial } \\
\text { ekonomi }\end{array}$ & 100 & 100,0 \\
2. tidak berpengaruh dalam peningkatan & 0 & 0,0 \\
kesejahteraan sosial ekonomi & 100 & 100,0 \\
\hline Jumlah & & \\
\hline
\end{tabular}

Political will pemilih figur kepemimpinan calon kepala desa dalam pembangunan pedesaaan berdampak meningkatkan bidang pendidikan diungkapkan oleh sebagian besar responden (84\%) dan responden lainnya (16\%) mengungkapkan bahwa political will pemilih figur kepemimpinan calon kepala desa dalam pembangunan pedesaaan tidak berdampak pada peningkatan bidang pendidikan.

\section{Tabel 8}

Political will pemilih figur kepemimpinan calon kepala desa dalam pembangunan pedesaaan berdampak 


\begin{tabular}{|c|c|c|}
\hline Alternatif jawaban & $\mathrm{F}$ & $\%$ \\
\hline 1. meningkatkan bidang pendidikan & 84 & $8 \overline{4,0}$ \\
\hline $\begin{array}{l}\text { 2. tidak berdampak pada peningkatan } \\
\text { bidang pendidikan }\end{array}$ & 16 & 16,00 \\
\hline Jumlah & 100 & 100,0 \\
\hline
\end{tabular}

Semua responden $(100 \%)$ menghendaki bahwa political will pemilih figur kepemmpinan calon kepala desa dalam pembangunan masyarakat pedesaan melakukan modernisasi di bidang pengangkutan dan teknologi.

\section{Tabel 9}

Political will pemilih figur kepemimpinan calon kepala desa dalam pembangunan masyarakat pedesaaan

\begin{tabular}{|c|c|c|}
\hline Alternatif jawaban & $\mathrm{f}$ & $\%$ \\
\hline $\begin{array}{l}\text { 1. melakukan modernisasi di bidang } \\
\text { pengangkutan dan teknologi }\end{array}$ & 100 & 100,0 \\
\hline $\begin{array}{l}\text { 2. tidak melakukan modernisasi di } \\
\text { bidang pengangkutan dan teknologi }\end{array}$ & 0 & 0,0 \\
\hline Jumlah & 100 & 100,0 \\
\hline
\end{tabular}

Separo lebih responden (69\%) mengemukakan bahwa political will pemilih figur kepemimpinan calon kepala desa dalam pembangunan masyarakat pedesaaan tidak mempersoalkan gender figur calon kepala desa, dan kurang dari separo responden $(31 \%)$ mengemukakan bahwa political will pemilih figur tepemimpinan calon kepala desa dalam pembangunan masyatakat pedesaaan mempersoalkan gender figur calon kepala desa.

Tabel 10

Political will pemilih figur kepemimpinan calon kepala desa dalam pembangunan masyarakat pedesaaan

\begin{tabular}{|ccc|}
\hline Alternatif jawaban & $\mathrm{f}$ & $\%$ \\
\hline
\end{tabular}




\begin{tabular}{|lll|}
\hline $\begin{array}{l}\text { 1. tidak mempersoalkan gender figur } \\
\text { calon kepala desa }\end{array}$ & 69 & 69,0 \\
$\begin{array}{l}\text { 2. mempersoalkan gender figur calon } \\
\text { kepala desa }\end{array}$ & 31 & 31,0 \\
\hline Jumlah & 100 & 100,0 \\
\hline
\end{tabular}

Hampir seluruh responden (94\%) berpendapat bahwa political will pemilih figur kepemimpinan calon kepala desa dalam pembangunan pedesaaan adanya perubahan, sedangkan responden lainnya $(6 \%)$ sangat sedikit berpendapat bahwa political will pemilih figur kepemimpinan calon kepala desa dalam pembangunan pedesaaan tetap.

Tabel 11

Political will pemilih figur kepemimpinan calon kepala desa dalam pembangunan

pedesaaan

\begin{tabular}{|llc|}
\hline \multicolumn{1}{|c|}{ Alternatif jawaban } & $f$ & $\%$ \\
\hline 1. Adanya Perubahan & 94 & 94,0 \\
2. Tetap & 6 & 6,0 \\
\hline Jumlah & 100 & 100,0 \\
\hline
\end{tabular}

\section{E. Kesimpulan dan Rekomendasi}

\section{Kesimpulan}

Bahwasanya sebagian besar responden (98\%) menyatakan bahwa political will pemilih figur kepemimpinan calon kepala desa berinisiatif dalam pembangunan masyarakat pedesaan. Selainnya, adalah sebagian kecil responden (2\%) tidak mempunyai inisiatif bagi kepemimpinan calon kepala desa dalam pembangunan masyarakat pedesaan.

Political will pemilih figur calon kepala desa dalam melakukan tugas kepemimpinannya pada umumnya responden $(82 \%)$ menyatakan adanya prioritas. Sedangkan sedikit responden $(12 \%)$ menyatakan tidak ada ada prioritas. 
Mobilisasi dukungan politik sebanyak 30\% responden, untuk mobilisasi pembangunan masyarakat lebih banyak responden (50\%) dibanding keduanya, dan tidak banyak responden $(20 \%)$ political will pemilih figur calon kepala desa dalam melakukan tugas kepemimpinannya berorientasi kepada mobilisasi pembangunan pemerintahan desa.

Penegakan hukum berupa hukuman yang berat bagi koruptor berjumlah $40 \%$ dan baik tidak ada hukuman yang berat bagi koruptor dan melaporkan kepada penegak hukum berjumlah sama masing-masing $21 \%$, serta $18 \%$ political will pemilih figur calon kepala desa dalam menjalankan kepemimpinan menekankan kepada tidak mengambil sikap.

Hampir semua responden ( $99 \%$ ) menyatakan bahwa political will pemilih figur calon kepala desa dalam menjalankan kepemimpinan berwawasan keberlanjutan usaha, dan hampir idak ada responden (1\%) menyatakan bahwa political will pemilih figur calon kepala desa dalam menjalankan kepemimpinan berwawasan tidak melanjutkan usaha.

Responden $(97 \%)$ menyatakan bahwa political will pemilih figur kepemimpinan calon kepala desa dalam pembangunan pedesaaan memperhatikan dengan memberi gairah dan semangat hidup baru serta menghilangkan monoton dari kehidupan desa, hanya $3 \%$ responden kurang memberi gairah dan semangat hidup baru serta menghilangkan monoton dari kehidupan desa, sedangkan responden lainnya masing-masing $0 \%$ atau tidak acia yang menyatakan tidak dan sama sekali tidak memberi gairah dan semangat hidup baru serta menghilangkan monoton dari kehidupan desa.

Tidak ada responden $(0 \%)$ yang menyatakan bahwa political will pemilih figur kepemimpinan calon kepala desa dalam pembangunan pedesaaan tidak berpengaruh dalam peningkatan kesejahteraan sosial ekonomi, jadi semua responden (100\%) menyatakan bahwa political will pemilih figur kepemimpinan calon kepala desa dalam pembangunan pedesaaan berpengaruh dalam peningkatan kesejahteraan sosial ekonomi.

Political will pemilih figur kepemimpinan calon kepala desa dalam pembangunan pedesaaan berdampak meningkatkan bidang pendidikan diungkapkan oleh sebagian besar responden $(84 \%)$ dan responden lainnya 
$(16 \%)$ mengungkapkan bahwa political will pemilih figur kepemimpinan calon kepala desa dalam pembangunan pedesaaan tidak berdampak pada peningkatan bidang pendidikan.

Semua responden (100\%) menghendaki bahwa political will pemilih figur kepemimpinan calon kepala desa dalam pembangunan masyarakat pedesaaan melakukan modernisasi di bidang pengangkutan dan teknologi.

Separo lebih responden (69\%) mengemukakan bahwa political will pemilih figur kepemimpinan calon kepala desa dalam pembangunan masyarakat pedesaaan tidak mempersoalkan gender figur calon kepala desa, dan kurang dari separo responden $(31 \%)$ mengemukakan bahwa political will pemilih figur kepemimpinan calon kepala desa dalam pembangunan masyarakat pedesaaan mempersoalkan gender figur calon kepala desa.

Hampir seluruh responden (94\%) berpendapat bahwa political will pemilih figur kepemimpinan calon kepala desa dalam pembangunan pedesaaan adanya perubahan, sedangkan responden lainnya $(6 \%)$ sangat sedikit berpendapat bahwa political will pemilih figur kepemimpinan calon kepala desa dalam pembangunan pedesaaan tetap.

\section{Rekomendasi}

Sehubungan dengan hasil temuan penelitian sebagaimana dalam kesimpulan tersebut, maka diberikan rekomendasi kepada:

a. Figur kepemimpinan calon kepala desa memikirkan tentang political will pemilih untuk pembangunan masyarakat pedesaan.

b. Kepala desa sebagai pemimpin terpilih seyogyanya memperhatikan political will pemilih dalam pembangunan masyarakat pedesaan.

c. Keduanya baik kepala desa pemimpin terpilih maupun pemilih sinergi melakukan program pembangunan masyarakat pedesaan bertumpu nilai-nilai luhur menuju masyarakat makmur, berasas pancasila, dan taat menjalankan agamanya. 


\section{DAFTAR PUSTAKA}

Ali Hanapiah. 2011. Fenomena Pembangunan Desa. Jatinangor: Institut Pemerintahan Dalam Negeri.

Bintarto. 1983. Interaksi Desa-Kota. Jakarta: Ghalia Indonesia.

Borg, Walter R., Gall, Meredith D. 1983. Educational Research: An Introduction (4 ${ }^{\text {th }}$ ed.) New York: Langman Inc.

Craig Charney. 2009. Political Will: What is it? How is it Measured? New York: Charney Research.

Dedi. 2012. Kepemimpinan. Universitas Bina Dharma. http://blog.binadarma.ac.id/dedi1968/wpontent/uploads/2012/09/kepe mimpinan.pdf

Derick W. Brinkerhoff. 1999. State-Civil Society Networks For Policy Implementation In Developing Countries. Review of Policy Research. Volume 16, Issue 1, pages 123-147, March 1999.

Gay, L.R. 1990. Educational Research: Competencies for Analysis and Application (3 ${ }^{\text {rd }}$ ed). New York: Macmillan Publishing Company.

Jacobs, T. O., and E. Jaques. 1990. Military executive leadership. In K.E. Clark and M. B. Clark, Measures of Leadership. West Orange, NJ: Leadership Library of America, Inc.

Joni Rahmat Pramudia. Pembangunan Masyarakat.

http://file.upi.edu/Direktori/FIP/JUR. PEND. LUAR SEKOLAH/1 27106141998031-

IONI RAHMAT PRAMUDIA/Pembangunan Masyarakat-HO.pdf

Khairuddin. 1992. Pembangunan Masyarakat Yogvakarta: Liberty.

Moleong, Lexy J. 2008. Metodologi Penelitian Kualitatif. Bandung : Rosdakarya.

Moeljarto Tjokrowinoto. 1977. Peranan Kebudayaan Politik, dan. Kebudayaan Administrasi di dalam Pembangunan Masyarakat Desa. Buletin No.3/1977. Yogyakarta: BPA, UGM.

Mochammad Teguh. 2001. Latiban Kepemimpinan Islam Tingkat Dasar (LKIDI). Yogyakarta: UII Press. 
Muhammad Ryaas Rasyid. 2000. Makna Pemerintahan. Jakarta: PT. Mutiara Sumber Widya.

Nadyafirdhani. 2012. National Power. Surabaya: Unair. http://nadvafirdhanifisip12.web.unair.ac.id/artikel detail-61768-Umum-

National\%20Power.html

Stoner, Freeman, dan Gilbert.1995. Management. US: Prentice Hall.

Suharsimi Arikunto. 2002. Prosedur Penelitian, Suatu Pendekatan Praktek. Jakarta: PT. Rineka Cipta

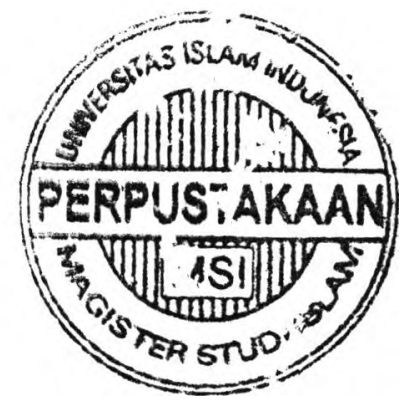

